\title{
Häckningsframgång hos ormvråk Buteo buteo och kattuggla Strix aluco i Varbergs kommun 1984-2016
}

\author{
Breeding success of Common Buzzard Buteo buteo and Tawny Owl Strix aluco in \\ Varberg, SW Sweden, in 1984-2016
}

\author{
BO KANJE \& SONJA KANJE
}

\begin{abstract}
In 1984-2016 we studied the habitat choice, nest placement and breeding success of Common Buzzard Buteo buteo and Tawny Owl Strix aluco in the municipality of Varberg in southwest Sweden $\left(57^{\circ} 10^{\prime} \mathrm{N}, 12^{\circ} 10^{\prime} \mathrm{E}\right)$. The analyses are based on 1512 successful breeding attempts of Common Buzzard, and 1387 of Tawny Owl. The average number of young per successful breeding was 1.74 and 2.86 , respectively. The variation between years was highly correlated between the two species, suggesting a common food source. In both species the between-year variation in clutch size was particularly large in beech forest territories, most like-

ly caused by the effect of beech mast years on local rodent populations. The breeding density of Common Buzzard was particularly high in 1990-1995, coinciding with large areas of farmland set-aside. In the Common Buzzard, the yearly average number of young per clutch declined significantly with yearly average hatching date.

Bo Kanje, Sonja Kanje, Droppstensgatan 1, lgh 10-02, 432 56 Varberg. E-mail: bo.kanje@telia.com.
\end{abstract}

Received 5 October 2017, Accepted 14 September 2018, Editor: Åke Lindström

\section{Inledning}

Som en del i verksamheten vid Getteröns Fågelstation startade vi 1984 ett projekt för att under fem år dokumentera situationen för våra dagrovfåglar och ugglor i en natur som ständigt förändras. Målsättningen var att finna så många häckande par som möjligt och att ringmärka ungarna. Projektet har löpande förlängts till och med 2016, om än med förändring i vilka arter som prioriterats. Den enda art som inte ingår är pilgrimsfalk som inventeras $i$ ett separat projekt.

Hela Halland, inklusive Varbergs kommun, inventerades i ett atlasprojekt 1973-1984, då häckande fåglar av alla arter registrerades. Denna inventering ingick i ett rikstäckande projekt (Svensson m.fl. 1999). För Halland var detta ett pionjärarbete och resultaten har också redovisats separat av Wirdheim \& Carlén (1986). Under 2005-2009 gjordes en ny inventering av Hallands fåglar (Wirdheim 2014). I atlasprojekten rapporterades fåglar efter olika häckningskriterier, men där ingick inte kontroll av hur fåglarna lyckades med sin häckning.

Skogs- och jordbruk har under det senaste halvseklet omvandlats dramatiskt såväl i Sverige som i Varbergs kommun. I jordbruket har många små gårdar slagits samman till stora enheter med ensartad odling, djurhållning har koncentrerats till ett fåtal stora gårdar. I brytningslandskapet öster om den halländska slätten har små jordbruk övergivits och markerna planterats med gran. Genom skogsbruket har rovfåglarnas häckningsbiotoper ändrats när gammal tall- och blandskog fällts och till stor del ersätts med granplanteringar. Därtill har på senare tid tillkommit potentiella problem för rovfåglarna i samband med vindkraftsetablering och bebyggelse i känsliga områden. För att kunna skydda våra rovfåglar och ugglor, krävs kunskap om såväl förekomst som häckningsframgång i utsatta områden. Målet med detta projekt var att bidra med sådan kunskap.

\section{Generella metoder}

Projektet har bedrivits i Varbergs kommun, belägen c. $70 \mathrm{~km}$ sydsydost om Göteborg $\left(57^{\circ} 10^{\prime} \mathrm{N}\right.$, $\left.12^{\circ} 10^{\prime} \mathrm{E}\right)$. Kommunen som omfattar ca $900 \mathrm{~km}^{2}$ ligger huvudsakligen i landskapet Halland, förutom att fyra socknar i nordost tillhör Västergötland. Hela kommunen ingår administrativt i Hallands län.

Vi har inventerat häckande rovfåglar och ugglor inom stora delar av kommunen under åren, med olika intensitet i olika områden (Figur 1). Ett av syftena med projektet har varit att se om rovfåglars och ugglors förekomst och häckningsframgång 
skiljer i de olika delarna av kommunen. Uppdelningen i fem områden gjordes dels efter landskapstyp och dels för enkelhetens skull efter större vägar i området. Förenklat kan kommunen delas i tre delar vad gäller landskapstyp; ett slättland närmast kusten med ett intensivt jordbruk (motsvarande område 1 i Figur 1), en mellanbygd med ett brutet landskap, bergsryggar upp till 100-150 m.ö.h. med jordbruk i dalgångarna, och längst i öster, ett mestadels skogklätt högland som är en del av sydsvenska höglandet, med altituder upp mot 200 m.ö.h. Områdena 2-5 (Figur 1) täcker både mellanregionen och skogsbygden.

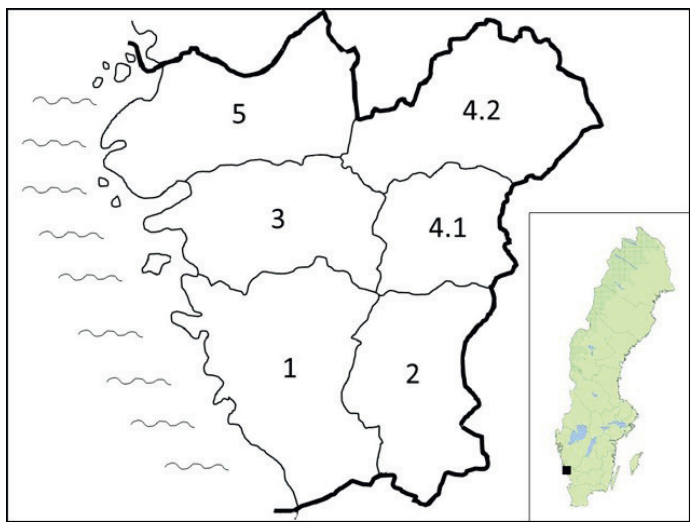

Figur 1. Varbergs kommun och de sex delområden som undersökts. Dessa är 1. Kustslätten, 2. Skogen i SO (huvudsakligen bokskog), 3. Mellanregionen, 4. Skogen i NO (varav 4.1 i ligger Halland och 4.2 ligger i Västergötland) och 5. Norra delarna.

The map shows the position of the Varberg municipality in Sweden, and the six parts of the study area. These are 1. The coastal plain, 2. The southeastern forests (which mainly consist of Beech), 3. The central region, 4. The northeastern forests (4.1 in the province of Halland, 4.2 in the province of Västergötland), and 5. The north.

Vi har försökt finna så många häckande par som möjligt och registrerat om de lyckats och hur många ungar de $\mathrm{i}$ så fall producerat. I samband med bobesök har vi ringmärkt främst ungar men också adulta ugglor. Boets höjd över marken, placering i olika trädslag och typ av skogar har också registrerats. Vi har däremot inte haft som mål att dokumentera bytesval och andra aspekter av deras biologi.

Under projektets gång har många revir försvunnit när skogar fällts, antingen genom skogsbruk eller stormar. Denna dynamik förändrar fågelsammansättningen och har gjort det svårt att följa enskilda revir och par kontinuerligt under studieperioden.
Förutom de landskapsförändringar som redan belysts ovan, är det viktigt att även nämna "Omställning 90”. Under perioden 1987-1995 gynnades gnagarspecialisterna tillfälligt genom ett förändrat jordbruksstöd. Markägare erbjöds ett omställningsstöd för att lägga sin mark i träda. Detta gynnade tillfälligt inte bara rovfåglar utan även många svenska jordbruksfåglar (Wretenberg m.fl. 2007).

Under åren har arbetet förskjutits från mest trädhäckande dagrovfåglar till mer tid för holkhäckande ugglor och tornfalk. Arbetet har utförts på fritid fram till 1997, därefter har vi som pensionärer använt vår tid med projektet året om, på heltid under vår och sommar. Två fokusarter har varit ormvråk och kattuggla och det är uppgifter om dessa arter som redovisas i denna artikel.

\section{Ormvråk}

\section{Metoder}

Ormvråken häckar oftast i skogarnas utkanter med möjlighet att jaga på öppna fält (Mebs 1964, Tubbs 1974, Reif m.fl. 2001, Dare 2015). Projektet startade efter att vi funnit ett häckande ormvråkspar på en oväntad plats, långt från öppen mark. Med start 1984 har vi systematiskt inventerat skogsdungar och större skogar efter rovfågelbon under höst och vinter. Boplatser registrerades med hjälp av GPS i systemet "Rikets nät". De fem år som avsetts räckte inte, vi har arbetat vidare och under åren inventerat i de flesta delarna av kommunen. Ett funnet risbo kan ha använts av flera arter. Både ormvråk, duvhök, bivråk och ugglor kan använda ett och samma bo. Sedan röd glada började häcka i kommunen utnyttjar också den befintliga ormvråksbon. Vi har även haft berguv som häckfågel 17 meter upp i ett ormvråksbo, där dock den enda ungen föll ner från boet och dog.

Kända och nya risbon som vi hittat under vintern har följts upp i april-maj för att konstatera om häckning pågår. Är boet tomt har vi granskat omgivningen efter nya alternativbon. På en del revir häckar fåglarna i samma bo i många år, i andra revir bygger de nya bon varje år. Beroende på skogsarbete eller andra omständigheter $\mathrm{i}$ omgivningen samt även fåglarnas överlevnad sker hela tiden förändringar i antalet besatta revir.

I andra halvan av maj månad och $\mathrm{i}$ juni har vi kontrollerat om det är ungar i bona. Har vi haft möjlighet har dessa ringmärkts. Som lyckad häckning $i$ våra presentationer räknas att ungar funnits i boet vid dessa besök. För att komma upp till boet har vi använt en byggbar stege. Varje del bygger $1 \frac{1}{2}$ meter, stegen hängs på en kraftig gren högt upp. Vi 
Tabell 1. Antal kontrollerade revir och häckningsframgång hos ormvråk inom Varbergs kommun perioden 1986-2011. Som häckningsförsök räknas ett färdigt bo med fåglar på boet eller varnande intill. Lyckad häckning innebär att det var ungar i boet vid kontroll. Antalet kullar där ungarna kunnat räknas framgår av kolumnen längst till höger.

Number of investigated territories and breeding success of Common Buzzard in Varberg, SW Sweden in 1986-2011. A bird on a nest or behaving alarmed next to it is considered a breeding attempt. A breeding attempt was considered successful if there were young in the nest. The number of clutches where the number of chicks could be counted are shown in the rightmost column.

\begin{tabular}{|c|c|c|c|c|c|c|c|}
\hline År & Revir & $\begin{array}{l}\text { Häcknings- } \\
\text { försök }\end{array}$ & $\begin{array}{c}\text { Andel } \\
\%\end{array}$ & $\begin{array}{c}\text { Lyckade } \\
\text { häckningar }\end{array}$ & $\begin{array}{c}\text { Andel } \\
\%\end{array}$ & $\begin{array}{l}\text { Ungar per lyckad } \\
\text { kull }\end{array}$ & Kullar \\
\hline Year & Territories & $\begin{array}{l}\text { Breeding } \\
\text { attempts }\end{array}$ & $\begin{array}{c}\text { Proportion } \\
\%\end{array}$ & $\begin{array}{l}\text { Successful } \\
\text { attempts }\end{array}$ & $\begin{array}{c}\text { Proportion } \\
\%\end{array}$ & $\begin{array}{l}\text { Young per success- } \\
\quad \text { ful breeding }\end{array}$ & Clutches \\
\hline 1986 & 23 & 21 & 91 & 20 & 95 & 1,33 & 18 \\
\hline 1987 & 62 & 55 & 89 & 39 & 71 & 1,41 & 37 \\
\hline 1988 & 73 & 49 & 67 & 37 & 76 & 2,23 & 31 \\
\hline 1989 & 95 & 67 & 71 & 50 & 75 & 2,15 & 41 \\
\hline 1990 & 121 & 91 & 75 & 71 & 78 & 1,95 & 64 \\
\hline 1991 & 139 & 100 & 72 & 62 & 62 & 1,36 & 53 \\
\hline 1992 & 142 & 89 & 63 & 62 & 70 & 1,62 & 55 \\
\hline 1993 & 161 & 111 & 69 & 81 & 73 & 1,89 & 54 \\
\hline 1994 & 179 & 107 & 60 & 80 & 75 & 1,58 & 71 \\
\hline 1995 & 189 & 102 & 54 & 66 & 65 & 1,34 & 59 \\
\hline 1996 & 165 & 99 & 60 & 74 & 75 & 1,75 & 28 \\
\hline 1997 & 163 & 82 & 50 & 46 & 56 & 1,36 & 25 \\
\hline 1998 & 170 & 90 & 53 & 69 & 77 & 1,74 & 43 \\
\hline 1999 & 166 & 98 & 59 & 79 & 81 & 2,24 & 45 \\
\hline 2000 & 146 & 74 & 51 & 50 & 68 & 1,52 & 23 \\
\hline 2001 & 128 & 68 & 53 & 53 & 78 & 1,96 & 25 \\
\hline 2002 & 112 & 56 & 50 & 38 & 68 & 1,62 & 26 \\
\hline 2003 & 139 & 73 & 53 & 54 & 74 & 2,05 & 20 \\
\hline 2004 & 138 & 69 & 50 & 48 & 70 & 1,45 & 20 \\
\hline 2005 & 138 & 79 & 57 & 65 & 82 & 1,70 & 30 \\
\hline 2006 & 161 & 77 & 48 & 62 & 81 & 1,50 & 30 \\
\hline 2007 & 126 & 68 & 54 & 58 & 85 & 2,00 & 26 \\
\hline 2008 & 146 & 50 & 34 & 38 & 76 & 1,83 & 18 \\
\hline 2009 & 114 & 46 & 40 & 40 & 87 & 2,10 & 21 \\
\hline 2010 & 123 & 51 & 41 & 42 & 82 & 2,15 & 20 \\
\hline 2011 & 109 & 38 & 35 & 23 & 61 & 1,53 & 15 \\
\hline Totalt & 3428 & 1910 & 56 & 1407 & 74 & 1,74 & 898 \\
\hline
\end{tabular}

kan i bästa fall nå 18 meter med hjälp av stegen. Ungar har hissats ner till marken och märkts, mätts och vägts. Fåglarnas val av boträd har noterats liksom boets höjd över marken. Skogen runt om boet har klassificerats efter om det är ensartad skog eller om det är blandskog, löv eller barr. Efter en för- siktig start 1984 drog arbetet igång i större skala 1986. Under perioden 1990-2011 kontrollerades över 100 revir årligen.

De flesta ungar som vi ringmärkt har vägts och längden på handpenna nr 5 har mätts, från spolen till spetsen. Med hjälp av detta mått samt delvis 
ungens vikt, har ålder och därmed en kläckningsdag för den äldsta ungen i kullen beräknats. Vi har utgått från en egen tabell som upprättades efter tillväxten på ett par kullar som vi följde i fem veckor de första åren. Vid några tillfällen under senare år har vi kunnat kontrollera vår skala när vi funnit bon med nykläckta ungar. Samma mått har använts under alla år även om tillväxten kan ha varierat beroende på födotillgång, kön och väder. Vår tabell stämmer väl överens med den beskrivning av ungars tillväxt som Dare (2015) presenterar. För varje år har vi sammanställt en medeldag för första ungen i årets kullar samt antal ringmärkningsstora ungar per kull under året.

\section{Resultat och diskussion}

Våra data sträcker sig över perioden 1984-2016 och de flesta av våra analyser inbegriper dessa år. För andra analyser har vi koncentrerat oss på den period där allra mest data samlades in, nämligen 1986-2011 (Tabell 1).

Antal kända revir var lågt $\mathrm{i}$ början, men efterhand som vi inventerade fler områden ökade antalet och var som flest under 1990-talet. Efter sekelskiftet har antalet revir som vi hunnit och kunnat kontrollera minskat. Andelen revir med häckförsök var högt i början när vi i första hand fann häckande fåglar på optimala platser. Med åren har andelen häckförsök minskat till stor del genom förändringar på skogarna genom skogsbruk och stormar. På många platser har vi inte funnit nya bon i närheten efter störningar och nyplanteringar. Minskningen beror också på att vi i början fann revir när de var aktiva. Med tiden ingick allt fler kända revir i våra studier och då är det naturligt att flera "tomma" revir noterades. Andelen lyckade häckningar var också högt första året samt de senare åren på 2000-talet, mest beroende på att många bra revir kontrollerats dessa år.

Flest antal kullar märktes de första tio åren när vi prioriterade ormvråk. Toppåret 1994 märktes 71 kullar med 111 ungar. Flest antal ungar under ett år, 1990, var 64 kullar med 123 ungar. Antal ungar per kull varierade mellan 1 och 4 (Tabell 2). Totalt märktes 483 kullar med 1,68 ungar per kull, 1986-1995. De följande tio åren, 1996-2005 märktes 285 kullar med 1,78 ungar per kull. Under 2006-2011 märkte vi 130 kullar med 1,85 ungar per kull. Det finns alltså en tendens till svag ökning i antal ungar per lyckad häckning. Denna trend är dock inte statistiskt signifikant (linjär regression på årsmedelvärdena, $\mathrm{b}=0,007 \pm 0,008(\mathrm{se}), \mathrm{p}=0.38)$, vilket åtminstone delvis beror på den stora variationen mellan olika år. Medelkullstorleken varierade mellan 1,33 och 2,24. Över alla åren var den genomsnittliga kullstorleken 1,74 märkstora ungar per par. Det är endast under de bästa åren fåglarna lyckas föda upp kullar med fyra ungar och i orm-

Tabell 2. Variationen i kullstorlek (antal ungar i boet) hos ormvråk (1984-2016) respektive kattuggla (1986-2016). Variation in brood size (number of young in the nest) in Common Buzzard (1984-2016) and Tawny Owl (1986-2016).

\begin{tabular}{|c|c|c|c|c|}
\hline \multirow{2}{*}{$\begin{array}{l}\text { Antal ungar } \\
\text { Number of young }\end{array}$} & \multicolumn{2}{|c|}{$\begin{array}{c}\text { Ormvråk } \\
\text { Common Buzzard }\end{array}$} & \multicolumn{2}{|c|}{$\begin{array}{l}\text { Kattuggla } \\
\text { Tawny Owl }\end{array}$} \\
\hline & $\begin{array}{r}\text { Kullar } \\
\text { Clutches }\end{array}$ & $\begin{array}{r}\text { Andel \% } \\
\text { Proportion \% }\end{array}$ & $\begin{array}{r}\text { Kullar } \\
\text { Clutches }\end{array}$ & $\begin{array}{r}\text { Andel \% } \\
\text { Proportion \% } \\
\end{array}$ \\
\hline 1 & 394 & 43,1 & 134 & 10,7 \\
\hline 2 & 380 & 41,5 & 348 & 27,9 \\
\hline 3 & 127 & 13,9 & 430 & 34,4 \\
\hline 4 & 14 & 1,5 & 248 & 19,9 \\
\hline 5 & & & 75 & 6,0 \\
\hline 6 & & & 12 & 1,0 \\
\hline 7 & & & 1 & 0,1 \\
\hline Totalt & 915 & 100 & 1248 & 100 \\
\hline
\end{tabular}


vråkens fall var det 1984, 1988 (2 kullar), 1990, 1993 (2), 1996, 1999 (2), 2001, 2003, 2007, 2009 och 2010. Av dessa var nio häckningar i ren bokskog, en i vardera ek, al, och tallskog. Två häckningar var i blandskog med löv.

Det finns flera publicerade studier att jämföra våra resultat med (Rockenbauch 1975, Spidsø \& Selås 1988, Goszczyński 1997, 2001, Reif m.fl. 2004, Rodríguez m.fl. 2010, Swan 2011, Douhan 2017) och vi har dessutom fått uppgifter direkt från andra ringmärkare i Sverige (Tabell 3). De rapporterade genomsnittliga kullstorlekarna, baserade på mycket stora material, varierar mellan 1,64 (de danska öarna, Jørgensen 1989) till 2,12 i Dalsland (Bengt Wiklund, i mail). Det man speciellt kan notera är att medelkullstorleken i det mest närliggande området, Falkenberg, (Thomas Dahlgren, i mail) var identisk med den i Varberg, och att båda dessa områden har jämförelsevis små kullar i genomsnitt. I alla rapporter betonas att tillgången på bytesdjur är den viktigaste faktorn för att fåglarna skall lyckas med sin häckning. Till exempel rapporterades det i den skånska studien om god tillgång på kanin (Sylvén 1982, Erlinge m.fl. 1983).

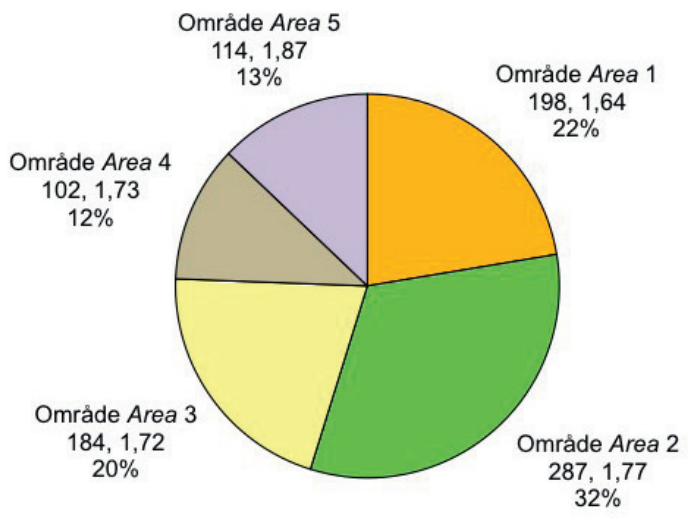

Figur 2. Häckningsframgång hos ormvråk 1984-2016 i de olika delområdena (30 kullar utanför kommungränsen ingår inte). För varje delområde anges antalet bon, medelantalet ungar per lyckad häckning, samt andelen av alla bon som påträffats i denna region. Delområdenas placering inom kommunen framgår av Figur 1. I figuren har data från delområdena 4.1 och 4.2 slagits samman.

Breeding success of Common Buzzards in 1984-2016 in the different study areas (Figure 1). For each area is given the number of nests, the average number of young per successful brood, and the proportion of the nests that were found in this area. The results from areas 4.1 and 4.2 have been lumped.
Sett över hela undersökningsperioden så varierade antal ungar per lyckad häckning ganska lite mellan de olika delarna av kommunen (Figur 2). Häckningarna i små dungar på jordbruksslätten (område 1) har det lägsta antalet ungar per kull $(1,64)$. Högst antal ungar har nordvästra delen av kommunen (område 5), ett område med varierat landskap. På exempelvis fyra revir har vi där ringmärkt sammanlagt 46 kullar med 100 ungar, ett snitt på 2,17 ungar per kull.

Vi delade in ormvråksreviren i två typer; de som i huvudsak bestod av bokskog respektive de i övriga habitattyper. Den sistnämnda gruppen domineras av revir med olika mängd jordbruksmark. Vad gäller det årliga antalet revir så kan noteras att antalet revir ökade starkt från 1986 fram till 1990, för att därefter ligga mycket högt under 90-talet (Tabell 1, Figur 3). Därefter en minskning igen. Denna period av ökat antal revir förklaras delvis av att stora mängder jordbruksmark lades i träda då, med påföljande ökning av frön och insekter, vilket gynnade många svenska fågelarter beroende av jordbrukslandskapet (Wretenberg m.fl. 2007). Högst rimligen gynnades även smågnagarna. Under samma period ökade ormvråkarna i antal över hela Sverige (Green m.fl. 2018). Någon motsvarande stor förändring i antalet häckande revir i bokskog fanns inte under perioden.

Det var tydligt större variation mellan åren i antalet ungar per kull i områden med mycket bokskog (Figur 4). Ollonår på hösten ger i allmänhet bra

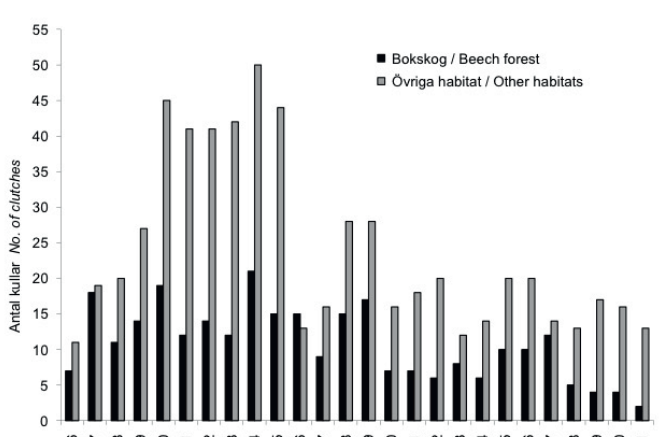

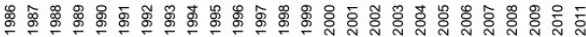

Figur 3. Antal ringmärkta kullar per år (1986-2011) i revir dominerade av bokskog respektive i övriga habitattyper. Notera det höga antalet kullar i övriga områden åren 19901995, år där stora ytor jordbruksmark lades i träda.

The number of ringed clutches per year (1986-2011) in territories dominated by beech forest and other habitats, respectively. The number of clutches in other habitats were particularly high in 1990-1995, when large areas of farmland were set aside. 
häckning i bokskogen året efter, vilket ger större variation på antalet ungar här än i andra områden samma år. Under sådana år kan ormvråk häcka långt från öppna marker.

De flesta funna ormvråksbon har varit belägna i tall, lika ofta i ren tallskog som i ensamma träd eller grupp av tallar i skogar med andra trädslag. Totalt 2040 häckförsök i 846 boträd har kontrollerats, 2,41 per träd (Tabell 4). Som mest har vi haft 2 bon med 16 häckförsök i samma träd, båda i tall. I det ena har fåglarna lyckats 15 gånger och vi har märkt 25 ungar i 12 kullar, 2,08 per kull. Efter senast konstaterade häckningen fälldes en stor del av skogen inklusive boträdet. I det andra boet med 16 häckförsök lyckades 11 häckningar, 9 kullar med 12 ungar märktes, 1,33 per kull.

Häckningsutfallet har perioden 1984-2016 registrerats i 1512 bon där också trädslag har registrerats och totalt lyckades $74,1 \%$ av häckningarna. Bäst lyckades häckning i alträd, 80,7 \% och sämst gick det i bok, $62,8 \%$. Det höga utfallet för övriga träd avser tillfälliga häckningar där trädslag inte noterats och i några gällde det asp, ask, lönn och lärk. Att fåglarna lyckas sämre i bok kan bero på att det är svårare att finna en bra grenklyka för boet, men också på att tillgången på gnagare i bokskogen plötsligt har kraschat så att fåglarna avbryter häckningen. När häckning i bok lyckas resulterar det dock oftast i fler ungar per kull (Figur 4).

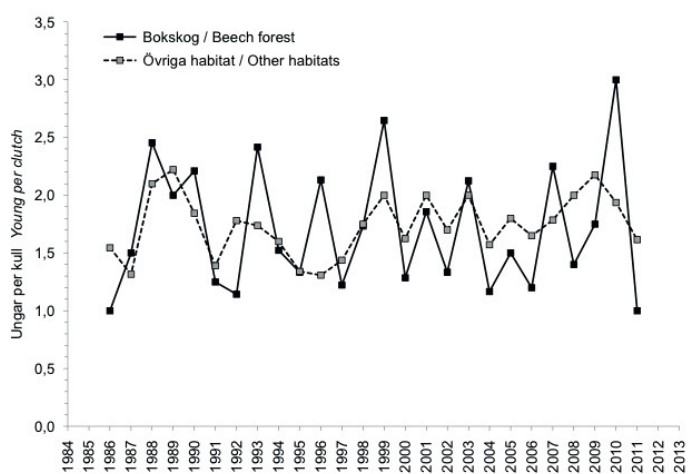

Figur 4. Det genomsnittliga antalet ormvråksungar per kull och år (1986-2011) i revir dominerade av bokskog respektive i övriga naturtyper. Notera att antalet ungar per år varierar mer mellan åren i bokskogen än i övriga områden.

The average number of Common Buzzard young per clutch and year (1986-2011) in territories dominated by beech forest, and in other habitats, respectively. The variation between years is larger in the beech forest than in the other habitats.

Ormvråkarnas bo placerades i allmänhet i den övre tredjedelen av boträdet, på mellan 10 och 15 $\mathrm{m}$ höjd (Tabell 5). Oftast låg boet intill stammen, men vi har även haft bon som legat flera meter ut på en eller ett par grenar. Ett bo i en ek låg endast fyra meter upp i trädet, det lägst liggande bo vi träffat

Tabell 3. Antalet ungar per kull hos ormvråk på andra platser i Sverige och Europa.

Average number of young in Common Buzzard clutches elsewhere in Sweden and Europe.

\begin{tabular}{lcccc}
\hline Plats & Period & Antal kullar & Antal ungar & $\begin{array}{c}\text { Ungar per } \\
\text { lyckad kull } \\
\text { Locality }\end{array}$ \\
No. of clutches & No. of young & $\begin{array}{c}\text { Young per suc- } \\
\text { cessful breeding }\end{array}$ & Source \\
\hline
\end{tabular}

\begin{tabular}{|c|c|c|c|c|c|}
\hline \multicolumn{6}{|l|}{ Sverige Sweden } \\
\hline Varberg & $1986-2010$ & 885 & 1540 & 1,74 & Denna studie This study \\
\hline Falkenberg & $1988-2003$ & 106 & 184 & 1,74 & Thomas Dahlgren, i mail \\
\hline Skåne & $1975-1980$ & & & 2,09 & Sylvén (1982) \\
\hline Dalsland & $1986-2010$ & 158 & 335 & 2,12 & Bengt Wiklund, i mail \\
\hline Göteborg & 1986-2005 & 135 & 271 & 2,01 & Jan Bergkvist, i mail \\
\hline Kungälv & $1986-2003$ & 57 & 118 & 2,07 & Tommy Järås, i mail \\
\hline Uppland & 1986-2010 & 416 & 875 & 2,10 & Bill Douhan, i mail \\
\hline \multicolumn{6}{|l|}{ Europa Europe } \\
\hline $\begin{array}{l}\text { Danska öarna Danish is- } \\
\text { lands }\end{array}$ & 1935-1987 & 627 & 1255 & 2,00 & Jörgensen (1989) \\
\hline Jylland, Danmark Denmark & 1973-1987 & 1260 & 2062 & 1,64 & Jörgensen (1989) \\
\hline Storbritannien The UK & & & & 1,69 & Dare (2015) \\
\hline
\end{tabular}




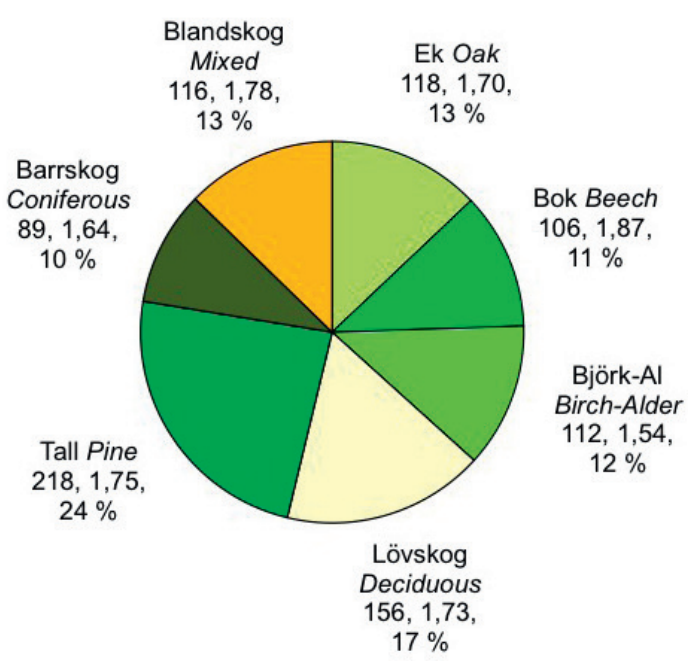

Figur 5. Häckningsframgång hos ormvråk 1984-2016, i relation till i vilken typ av skog boet varit placerat. För varje skogstyp anges det dominerande trädslaget. "Lövskog" utgörs av lövträd av olika slag, "Barrskog” är en blandning av tall, gran och lärk och "Blandskog" innehåller både löv- och barrträd. För varje skogstyp anges antalet bon, medelantalet ungar per lyckad häckning, samt andelen av alla bon som påträffats i denna skogstyp.

Breeding of Common Buzzards in 1984-2016 in relation to the type of forest where the nest was placed. Each forest type is named after the dominating tree species. "Deciduous" consist of various species of deciduous trees, "Mixed coniferous" consist of pine, spruce and larch, and "Mixed" consist of both deciduous and coniferous trees. For each forest type is given the number of nests, the average number of young per successful brood, and the proportion of the nests that were found in this forest type.

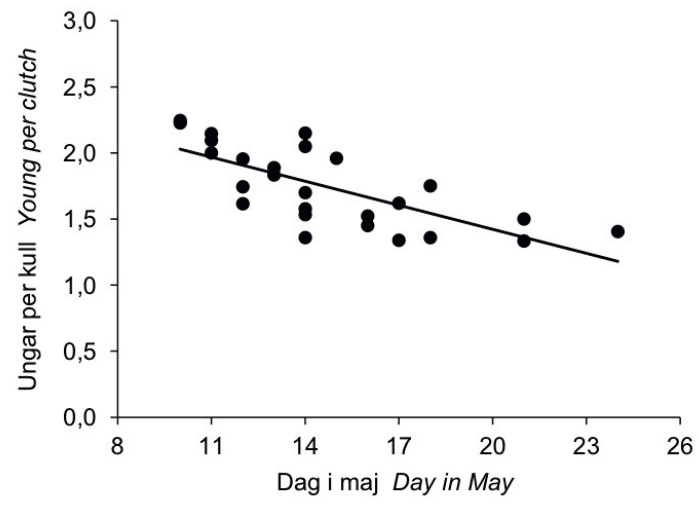

Figur 6. Medelantalet ungar per lyckad häckning och år hos ormvråk 1986-2011, i förhållande till det årliga medelvärdet för kläckningsdatumet hos första ungen i varje kull.

The average number of young per successful breeding and year in Common Buzzards in 1986-2011, in relation to the yearly average of the estimated hatching date for the first young in each clutch.

på, men trädet stod i en brant så att fåglarna ändå hade fritt utflyg neråt i branten. Två andra bon 4-5 meter över marken, i tall respektive björk, var båda på en trädbevuxen mosse med öppnare ytor intill.

Fåglarnas val av boträd, som redovisats ovan, avviker ganska ofta mot den kringliggande skogens sammansättning. Vi har därför även grovt klassificerat de skogar där vi funnit och ringmärkt ormvråksungar. Klassningen bygger på det huvudsakliga trädbeståndet inom 100 meter från boet (Figur 5). Det var inga dramatiska skillnader i

Tabell 4. Boträdsval hos ormvråk 1984-2016. Antalet kullar där ungarna kunnat räknas framgår av kolumnen längst till höger.

Choice of tree species by nesting Common Buzzards. The number of clutches where the number of chicks could be counted are shown in the rightmost column.

\begin{tabular}{|c|c|c|c|c|c|c|c|}
\hline $\begin{array}{l}\text { Trädslag } \\
\text { Tree species }\end{array}$ & $\begin{array}{c}\text { Antal } \\
\text { Träd } \\
\text { No. of } \\
\text { trees }\end{array}$ & $\begin{array}{l}\text { Andel } \\
\text { Pro- } \\
\text { portion } \\
\%\end{array}$ & $\begin{array}{l}\text { Häcknings- } \\
\text { försök } \\
\text { Breeding } \\
\text { attempts }\end{array}$ & $\begin{array}{c}\text { Lyckade } \\
\text { häckningar } \\
\text { Successful } \\
\text { attempts }\end{array}$ & $\begin{array}{c}\text { Andel } \\
\text { Pro- } \\
\text { portion } \\
\%\end{array}$ & $\begin{array}{l}\text { Ungar per lyck- } \\
\text { ad häckning } \\
\text { Young per suc- } \\
\text { cessful breeding }\end{array}$ & $\begin{array}{l}\text { Kullar } \\
\text { Clutches }\end{array}$ \\
\hline Ek Oak & 158 & 18,7 & 403 & 284 & 70,5 & 1,79 & 183 \\
\hline Bok Beech & 45 & 5,3 & 129 & 81 & 62,8 & 2,09 & 45 \\
\hline Björk Birch & 120 & 14,2 & 331 & 238 & 71,9 & 1,66 & 124 \\
\hline Al Alder & 87 & 10,3 & 218 & 176 & 80,7 & 1,62 & 81 \\
\hline Tall Pine & 339 & 40,1 & 766 & 578 & 75,5 & 1,76 & 383 \\
\hline Gran Spruce & 61 & 7,2 & 159 & 126 & 79,2 & 1,63 & 96 \\
\hline Övriga Other & 36 & 4,3 & 34 & 29 & 85,3 & 1,00 & 3 \\
\hline Totalt & 846 & 100 & 2040 & 1512 & 74,1 & 1,74 & 915 \\
\hline
\end{tabular}


Tabell 5. Boets höjd över marken (i meter) hos ormvråk 1984-2016, beroende på trädslag.

The height above the ground (in meters) of Common Buzzard nests 1984-2016, in relation to tree species.

\begin{tabular}{lccccc}
\hline & $\begin{array}{c}\text { Antal träd } \\
\text { No. of trees }\end{array}$ & $\begin{array}{c}\text { Andel } \% \\
\text { Proportion }\end{array}$ & Min & $\begin{array}{c}\text { Medel } \\
\text { Average }\end{array}$ & Max \\
\hline Ek Oak & 115 & 18,7 & 4,0 & 11,8 & 23,5 \\
Bok Beech & 34 & 5,5 & 9,0 & 14,9 & 21,5 \\
Björk Birch & 88 & 14,3 & 5,0 & 12,0 & 20,5 \\
Al Alder & 55 & 9,0 & 8,0 & 13,3 & 20,0 \\
Tall Pine & 261 & 42,5 & 4,3 & 12,7 & 20,0 \\
Gran Spruce & 55 & 9,0 & 8,0 & 13,1 & 22,0 \\
Övriga Other & 6 & 1,0 & 8,0 & 10,8 & 14,0 \\
\hline Totalt & 614 & 100 & & 12,6 & \\
\hline
\end{tabular}

häckningsframgång mellan de olika skogstyperna perioden 1984-2016, men den genomsnittliga häckningsframgången var högst i bokskog $(1,87$ ungar per bo) och minst i björk-alskog (1,54 ungar per bo, Figur 4).

Genomsnittlig kläckingsdag för första ungen hos ormvråk varierade både mellan kullar och mellan år. Kläckningsdag för första ungen i ett års kullar kunde skilja upp till trettio dagar. Det årliga genomsnittliga antalet ungar per kull minskade generellt med tid på säsongen för kläckningen (linjär regression på årsmedelvärdena, $\mathrm{b}=-0,061 \pm 0,012$ (se), $\mathrm{p}<0,001$, Figur 6). Det betyder att för varje dag i maj som gick, så blev det i genomsnitt 0,061 färre ungar i kullarna. Årsmedelvärdet för kläckningen av första ungen varierade mellan 10 maj (1988 och 1989) och 24 maj (1987). I den största delen av kullarna under 1986-2011 (663 av 898, $74 \%$ ), har första ungen kläckts under perioden 6-20 maj. Några år har vi haft ormvråksungar som kläckts sista veckan i april. Senaste beräknade kläckningsdag var den 13 juni, en unge som inte kunde ringmärkas förrän den nionde juli.

Minskningen av kullstorleken över tiden kan också beskrivas på följande sätt. I årskullar med genomsnittlig kläckning 10-12 maj (297 kullar med 596 ungar) var medelkullstorleken 2,01 ungar per kull. För perioden 13-16 maj (321 kullar 552 ungar) var det 1,72 ungar per kull och för perioden 17-24 maj (280 kullar 410 ungar) var det 1,46 ungar per kull.

\section{Ormvråken i Varbergs kommun}

Efter 1950 och 1960-talens giftskandal med kvicksilverbetat utsäde, som påverkade bytesdjur i första skedet och därefter våra rovfåglar, har antalet fåg- lar ökat ganska snabbt. Redan när vi började inventera efter ormvråk var beståndet ganska väl återställt. Då en del odlingsmarker under 1990-talet lades i träda ökade antalet häckande ormvråkspar ute på jordbruksslätten (jmf. den positiva effekten på många jordbruksfåglar, Wretenberg m.fl. 2007). Senare har flera av dessa par försvunnit i samband med att det mesta av jordbruksmarken åter började brukas.

En annan påverkan på beståndets storlek är att antalet gårdar som håller nötboskap minskar drastiskt. Djuren samlas på ett fåtal gårdar och gräs som odlas till deras försörjning slås fyra fem gånger under sommaren. Genom detta minskar ytor med naturbete som kan vara tillhåll för sork och möss. Igenläggning av dike och sammanslagning av åkrar, för att få större ytor att arbeta på, försämrar också möjligheten för bytesdjur och predatorer.

I Varbergs kommun och Halland i helhet, som för 150 år sedan (Malmström 1939) var ett tämligen skogfattigt landskap, planterades runt förra sekelskiftet och framåt andra världskriget stora ytor med skog och landytan är numera täckt till hälften med skog. Det som planterades i början var till en stor del tall. Denna skog tillsammans med lövskog som fanns var bra för våra fåglar. Runt 1950 täckte planterad granskog mindre än en fjärdedel av skogsarealen (Länsstyrelsen i Halland 2007). Sedan dess har ytterligare stora ytor med ängsoch betesmark planterats. Bara under de senaste 30 åren, >1994, har granskogsarealen fördubblats (Länsstyrelsen i Halland 1994.) Andelen gran i kommunen är numera dubbelt så hög som riksgenomsnittet. Andelen kommer att öka genom att nyplantering görs till mer än $80 \%$ av gran (Länsstyrelsen i Halland 2007). Projektet har nästan pågått i en halv skogsgeneration och vi har under tiden 
Tabell 6. Antal kontrollerade revir och häckningsframgång hos kattuggla i Varbergs kommun perioden 1986-2016. Som häckningsförsök räknas holk med uggla som lagt ägg. Lyckad häckning innebär att det är ungar i boet vid kontroll. Antalet kullar där ungarna kunnat räknas framgår av kolumnen längst till höger.

Number of territories visited and breeding success of Tawny Owl in Varberg, SW Sweden in 1986-2016. A nest box with an owl and at least one egg is considered a breeding attempt. A breeding attempt was considered successful if there were young in the nest. The number of clutches where the number of chicks count be counted are shown in the rightmost column.

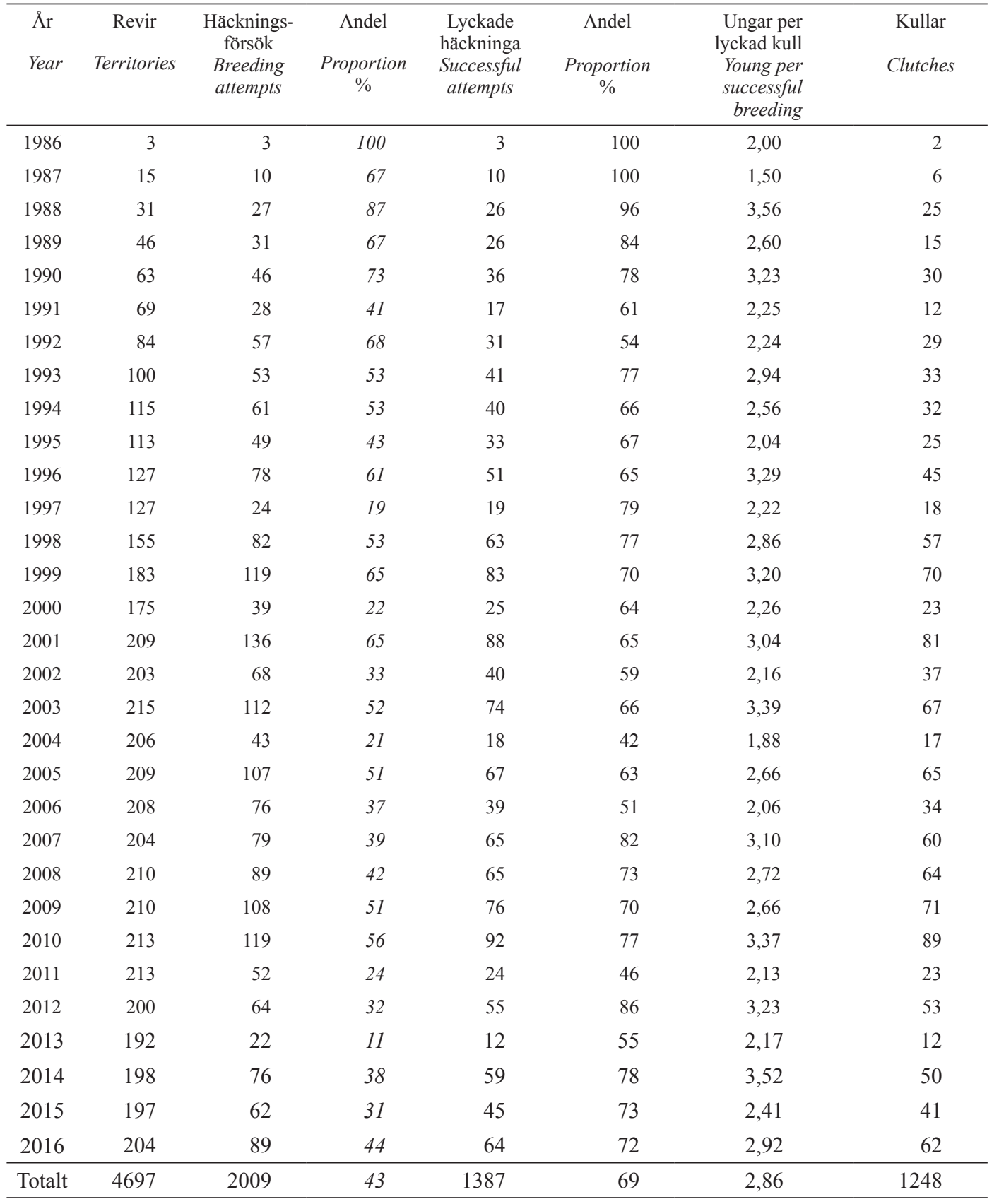



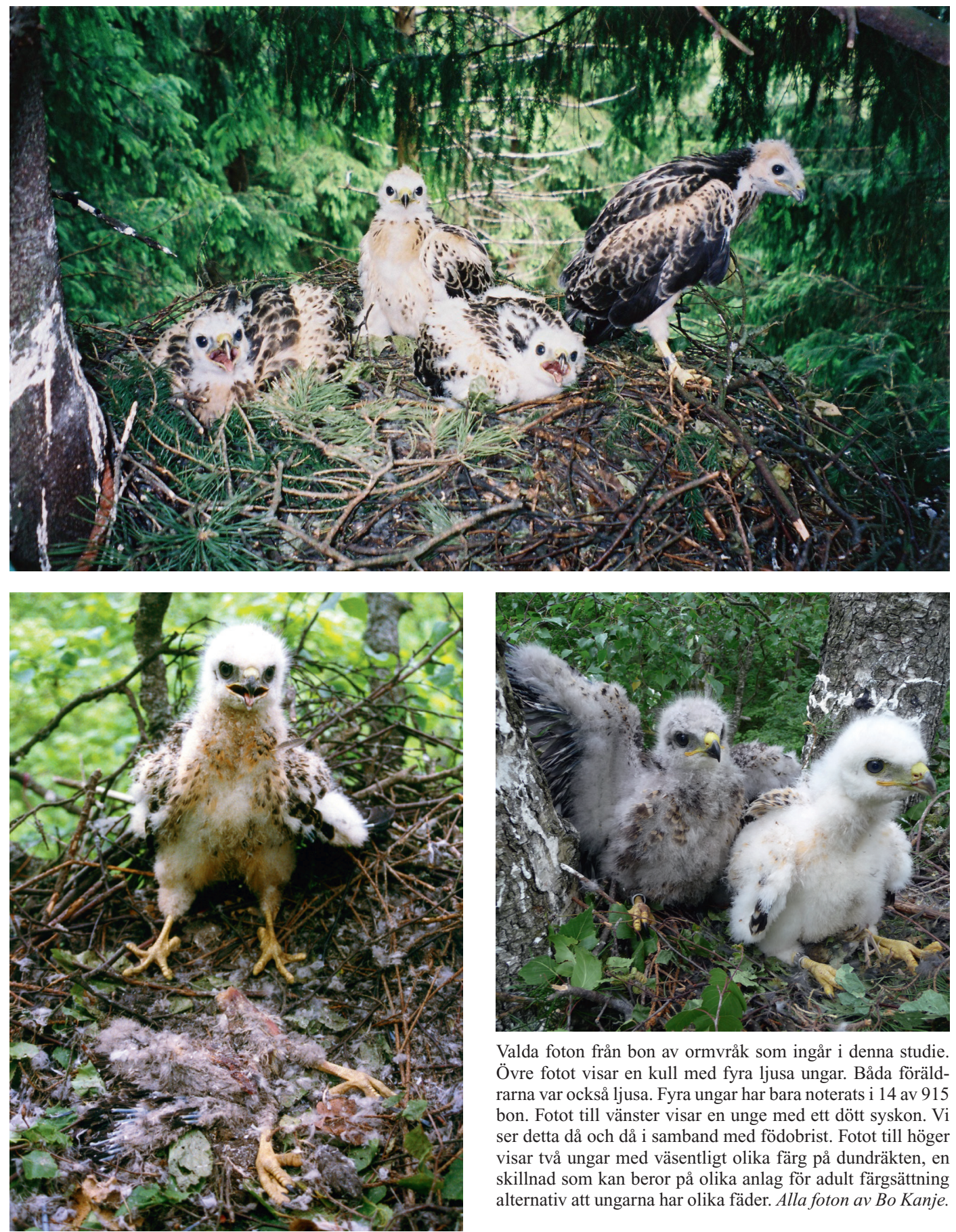

Valda foton från bon av ormvråk som ingår i denna studie. Övre fotot visar en kull med fyra ljusa ungar. Båda föräldrarna var också ljusa. Fyra ungar har bara noterats i 14 av 915 bon. Fotot till vänster visar en unge med ett dött syskon. Vi ser detta då och då i samband med födobrist. Fotot till höger visar två ungar med väsentligt olika färg på dundräkten, en skillnad som kan beror på olika anlag för adult färgsättning alternativ att ungarna har olika fäder. Alla foton av Bo Kanje.

Photos of Common Buzzards from this study. The upper photo shows a brood of four pale young. Both parents were of the pale colour morph. Four young have only been noted in 14 out of 915 nests. The photo to the left shows a young with a dead sibling. We saw this happen occasionally in times of food shortage. The photo to the right shows two young of different down colour, a difference possibly related to adult colour morphs. Alternatively, the young had different fathers. 


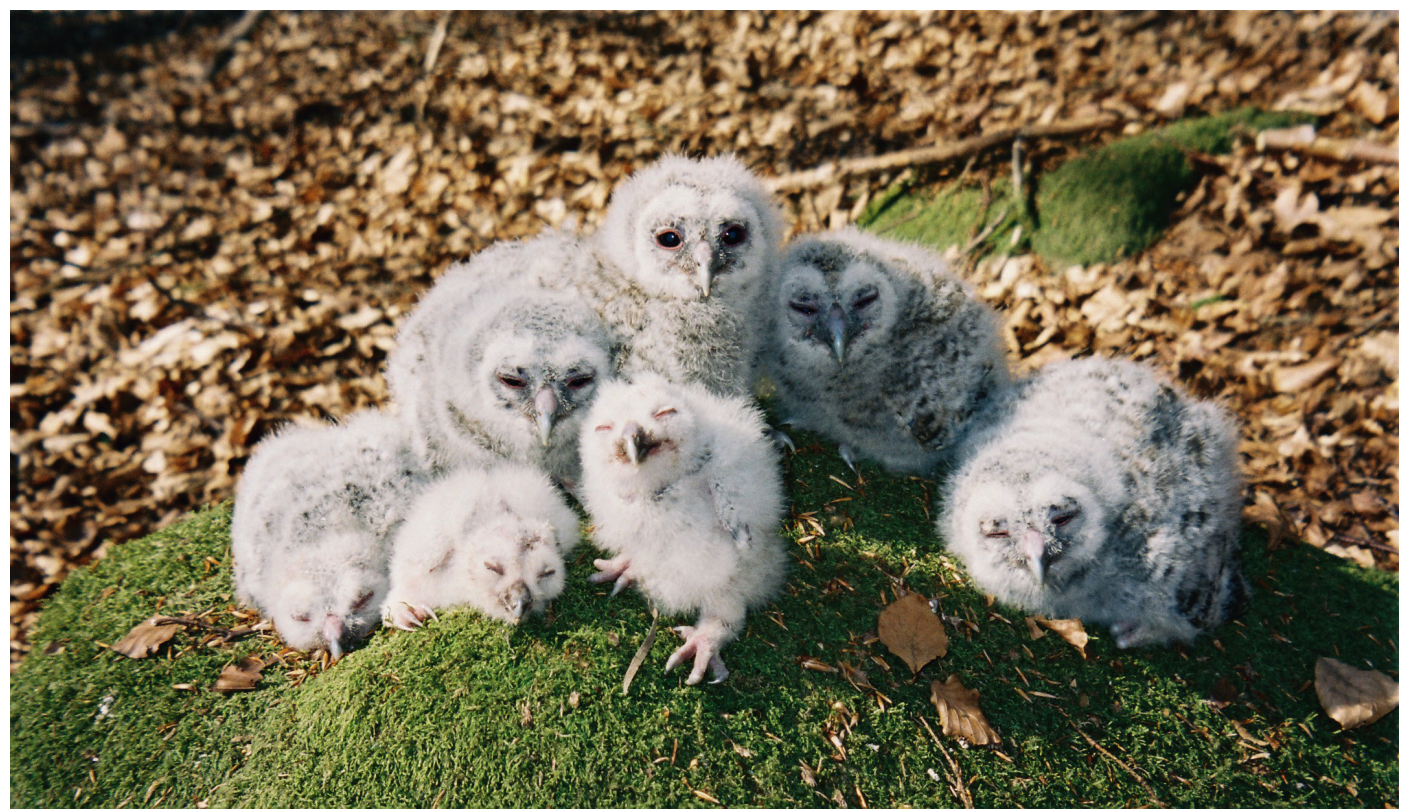

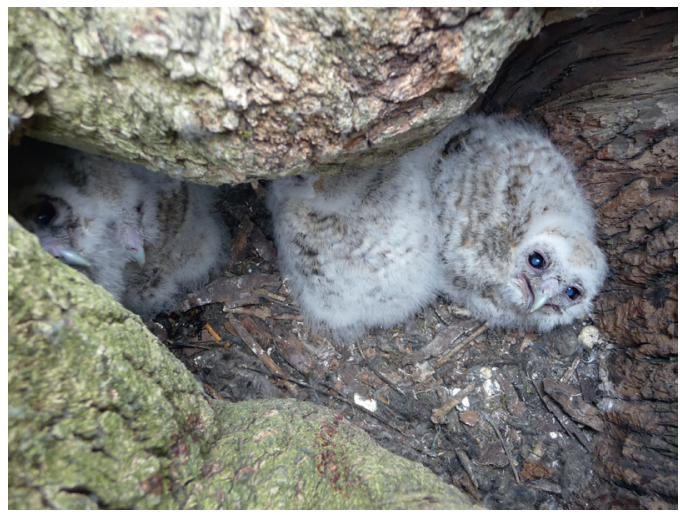

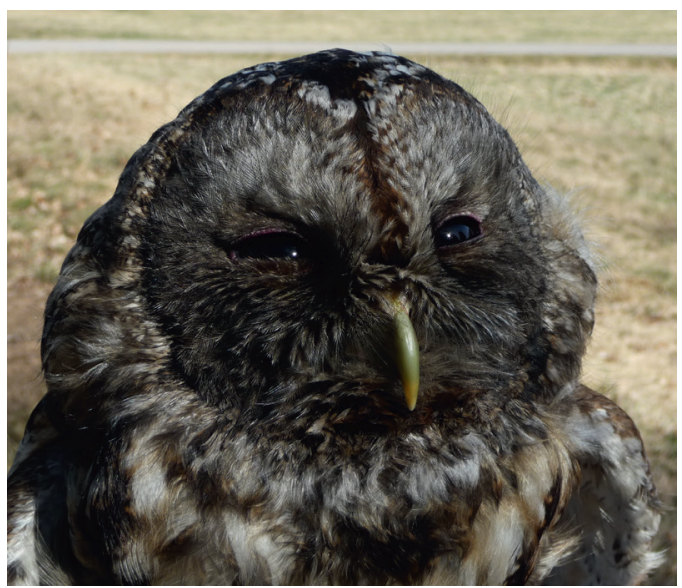

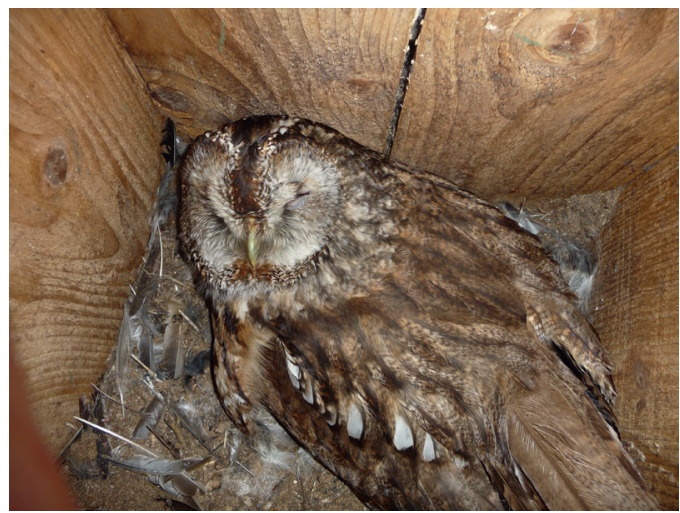

Valda foton av häckande kattugglor som ingår i denna studie. Det översta fotot visar en kull med sju ungar, vilket är den största och enda kullen med detta antal ungar. Alla ungar blev flygga. Kattugglorna har häckat i såväl naturliga håligheter som i holkar. I ett fåtal fall har avvikande färgdräkter noterats, till exempel den mycket mörka fågeln på fotot till vänster.

Photos of Tawny Owls from this study. The upper photo shows the only recorded brood of seven young. This is the largest brood recorded and all of the young fledged. Tawny Owls were found to breed in natural cavities as well as in nest boxes. Sometimes owls with aberrant colour morphs were found, such as the very dark individual seen in the lower left photo. 
sett en stor förändring på många rovfågelrevir. Under de senaste åren har en hel del av den vuxna tall- och blandskogen fällts. Det mesta som är kvar kommer att fällas inom kort och till största delen ersätts allt med granplanteringar. Detta kommer att betyda en försämring för fåglarnas födotillgång.

Även om vi inte specifikt undersökt födotillgången för Varbergs ormvråkar så är vi övertygade om att variationen i antalet häckande ormvråkspar varierar mellan åren i huvudsak beror på födotillgången (Sylvén 1982). Även om det är brist på föda häckar många par, men häckning påbörjas oftast senare. De lägger då färre ägg och antalet flygga ungar blir lågt.

Antal ungar per häckförsök 1986-2011 kan inte anges exakt, men kan beräknas som antal lyckade kullar (1407), multiplicerat med genomsnitt märkta per kull $(1,74)$ och dividerat med antal häckförsök (1910). Det blir ungefär 1,28 ungar per häckförsök. Vår ringmärkning visar inga väsentliga skillnader på antal ungar per kull i olika områden inom kommunen. Däremot finns det stora skillnader mellan olika revir inom varje del.

Vi har ingen given förklaring till att antalet ungar per kull är lägre i Varberg än vad andra undersökningar från Sverige och Europa visar (Tabell 3). Vi har ännu till synes gynnsamma förhållande med ett varierat landskap. Dock är populationen tämligen tät, vilket kan påverka revirens storlek och därmed fåglarnas födosöksmöjlighet. God förekomst av vildkanin som födoresurs gör att ormvråken kan producera fler ungar (Sylvén 1982). Vildkanin förkommer dock normalt inte i de områden där vi har häckande ormvråk.

Halland har en kalkfattig berggrund och läget i sluttningen mot sydsvenska höglandet ger mer regn än genomsnittligt för landet vilket kan innebära större förluster av ungar än i ett torrare område. Med regnet följer också ett stort nerfall av föroreningar.

I kommunens olika delar är det klart mest häckningar per ytenhet i brytningslandskapet mellan slätt och skogsbygd. Jordbruksslätten har endast ett fåtal mindre skogsdungar och ett fåtal häckande par. Lite gynnsammare var det ett antal år när lantbruket lade marker i träda. Skogsbygden i öster består numera till stor del av sammanhängande skogar. Här fanns för mer än hundra år sedan många små gårdar och torpställen. De flesta markerna runt dessa är numera planterade med gran. Ormvråk finner man där oftast i samband med kvarvarande mindre jordbruk och i enstaka fall intill stora hyggen.

\section{Kattuggla}

\section{Inledning}

Redan tidigt $i$ vårt projekt om rovfåglar $i$ Varbergs kommun började vi sätta upp holkar för kattuggla. Det visade sig ganska snart när vi inventerade att det var stor brist på boträd för ugglor. I det gamla jordbrukslandskapet med mycket betes- och ängsmark fanns det en hel del träd utmed odlings- och ägogränser med lämpliga boplatser för ugglorna, med jaktmark på fälten runt om. Men ett effektivt skogs- och jordbruk och moderna byggnader har minskat tillgången på såväl lämpliga boplatser som bytesdjur. Avsikten med projektet var att få kunskap om kattuggla inom kommunen i allmänhet och variation $\mathrm{i}$ antal häckningar och hur fåglarna lyckades med denna i synnerhet. Här finns det undersökningar av kattuggla inom andra områden som det går att jämföra med (Philipsson 2001, Ericsson m. fl. 2014).

Kattugglor är beroende av god gnagartillgång för sin häckning och de reagerar på födobrist betydligt mer än vad ormvråk gör vilket märks på att såväl antalet häckningar som antal ungar i kullen varierar mycket mellan åren (Wallin 1988, Persson 2003). I vårt område fanns störst antal häckande par $\mathrm{i}$ mellanbygden, området mellan jordbruksslätten i väster och de stora skogsområdena i öster. Mellanbygden präglas av kuperade marker med jordbruk i dalar, många sjöar och våtmarker, samt en hel del lövskog. Samtidigt är det i mellanbygden som små gårdar läggs ner och marker planteras med skog.

\section{Metoder}

De första holkarna i projektet sattes upp hösten 1985 och våren därefter häckade några par kattugglor. Antalet holkar ökades fram till mitten på 90-talet. Vi har därtill kontrollerat en del holkar som har satts upp av markägare på olika platser inom kommunen samt några häckningar i uthus eller $\mathrm{i}$ vårdträd vid gårdar. Från 1998 har vi haft över 300 kattuggleholkar som sedan 2010 minskat något på grund av stormar och skogsarbete. I flera revir har vi haft två holkar. Ugglorna tycks uppskatta detta och byter ofta holk mellan åren. Med ett par undantag satt alla holkar inom Varbergs kommun.

Holkar har satts upp i närheten av öppna marker där vi har uppfattat området som attraktivt. De flesta holkarna hängdes med ett band runt trädet så att de går att flytta. De sattes i regel fyra meter upp, lite beroende på omgivningen. Vi har endast flyttat holkar om vi fått veta att skogen skall fällas. Tyvärr har många träd, med holkar, fällts i samband med avverkning utan att vi fått möjlighet att flytta dem. 
Tabell 7. Genomsnittlig kullstorlek (antal ägg eller ungar) hos kattuggla i Varbergs kommun 1996-2016. I kolumnerna till vänster visas data för kullar som haft ägg vid den första bokontrollen. I kolumnerna till höger visas antalet ungar som ringmärkts i kullar där det fanns ungar vid den första bokontrollen.

Average clutch size (eggs and nestlings) of Tawny Owl in Varberg, SW Sweden in 1998-2016. The columns to the left show data for nests containing eggs at the first nest check, and the subsequent number of young. The columns to the right show the number of young ringed in nests where there were nestlings already at the first check.

\begin{tabular}{|c|c|c|c|c|c|c|}
\hline \multirow[b]{2}{*}{$\begin{array}{l}\text { År } \\
\text { Year }\end{array}$} & \multicolumn{3}{|c|}{$\begin{array}{l}\text { Kullar med ägg vid första kontrollen } \\
\text { Clutches with eggs at first check }\end{array}$} & \multirow[b]{2}{*}{$\begin{array}{l}\% \text { kläckta } \\
\% \text { hatched }\end{array}$} & \multicolumn{2}{|c|}{$\begin{array}{l}\text { Kullar med ungar vid första kontrollen } \\
\text { Clutches with young at first check }\end{array}$} \\
\hline & $\begin{array}{l}\text { Kullar } \\
\text { Clutches }\end{array}$ & $\begin{array}{l}\text { Ägg per kull } \\
\text { Eggs per } \\
\text { clutch }\end{array}$ & $\begin{array}{l}\text { Ungar per kull } \\
\text { Young per clutch }\end{array}$ & & $\begin{array}{r}\text { Kullar } \\
\text { Clutches }\end{array}$ & $\begin{array}{l}\text { Ungar per kull } \\
\text { Young per clutch }\end{array}$ \\
\hline 1998 & 31 & 3,84 & 2,65 & 68,9 & 26 & 3,12 \\
\hline 1999 & 37 & 4,57 & 3,35 & 73,4 & 33 & 3,03 \\
\hline 2000 & 9 & 2,78 & 2,00 & 72,0 & 14 & 2,43 \\
\hline 2001 & 59 & 4,42 & 3,07 & 69,3 & 22 & 2,95 \\
\hline 2002 & 22 & 2,73 & 2,09 & 76,7 & 15 & 2,27 \\
\hline 2003 & 51 & 4,45 & 3,37 & 75,8 & 16 & 3,44 \\
\hline 2004 & 13 & 2,62 & 2,00 & 76,5 & 4 & 1,50 \\
\hline 2005 & 41 & 3,83 & 2,66 & 69,4 & 24 & 2,67 \\
\hline 2006 & 22 & 3,32 & 1,91 & 57,5 & 12 & 2,33 \\
\hline 2007 & 16 & 3,50 & 2,50 & 71,4 & 44 & 3,32 \\
\hline 2008 & 32 & 3,25 & 2,38 & 73,1 & 32 & 3,06 \\
\hline 2009 & 43 & 3,42 & 2,51 & 73,5 & 29 & 2,93 \\
\hline 2010 & 58 & 4,22 & 3,31 & 78,4 & 31 & 3,48 \\
\hline 2011 & 18 & 2,67 & 2,11 & 79,2 & 5 & 2,20 \\
\hline 2012 & 8 & 3,13 & 2,38 & 76,0 & 45 & 3,38 \\
\hline 2013 & 5 & 2,20 & 2,00 & 90,9 & 7 & 2,29 \\
\hline 2014 & 3 & 3,33 & 2,33 & 70,0 & 47 & 3,60 \\
\hline 2015 & 30 & 3,10 & 2,27 & 73,1 & 11 & 2,82 \\
\hline 2016 & 48 & 3,52 & 2,85 & 81,1 & 14 & 3,14 \\
\hline Summa & 546 & 3,72 & 2,74 & 73,5 & 431 & 3,08 \\
\hline
\end{tabular}

Om det funnits en bra alternativ plats på reviren har vi då satt upp en ny holk för att inte förlora kontakten med de ugglor som vi kanske följt i många år.

Vi har försökt kontrollera samtliga holkar flera gånger varje år, oftast $\mathrm{i}$ april och maj, några tidiga år redan i slutet av mars. Häckande honor har fångats, om det varit möjligt, och ringmärkts eller kontrollerats. Vi försöker fånga honorna när det är små ungar i holken, men ibland blir det medan de ruvar. Efter kontroll har fåglarna lagts in i holken igen. I de fall då vi kunnat kontrollera antal ägg har detta registrerats för att kunna jämföra med antal märkstora ungar senare. Ungar har i huvudsak ringmärkts i en ålder av två till tre veckor. Ungar har vägts och längden på handpenna fem har mätts för att kunna uppskatta ålder och ordning $\mathrm{i}$ syskonskaran. Uppgifterna kan bl.a. användas för att se vilka ungar i kullen vi får flest kontroller av som häckande honor. I samtliga fall där vi märkt ungar har det skett när ungarna varit lagom stora. I några enstaka fall har den minsta ungen varit långt efter i utveckling och mer eller mindre livlös vid besöket, vi har då avstått från att märka denne. Sådana ungar, som är svältfödda, har liten möjlighet att bli flygga. Dessa fåtal ungar ingår inte i nedanstående uppgift om kullstorlek. 


\section{Resultat och diskussion}

Under åren 1986-2016 har vi noterat 2009 häckförsök, varav $69 \%$ räknats som lyckade fram till vår senaste kontroll (Tabell 6). Av dessa lyckade häckningar har vi kunnat ringmärka $90 \%$, nämligen 1248 kullar med 3566 ungar. Resterande kullar, 10 $\%$, har vi inte hunnit besöka medan ungarna varit $\mathrm{i}$ rätt storlek.

Ugglornas häckframgång varierar stort mellan åren, både andelen som påbörjar häckning, hur de lyckas och det antal ungar som fåglarna lyckas föda upp. Tillgången på föda avgör om ugglorna går till häckning eller avstår under året. Proportionen påbörjade häckningar i våra holkar, $43 \%$, stämmer väl med de $42 \%$ som redovisats i ett motsvarande projekt i närbelägna Västergötland (Ericsson $\mathrm{m}$. fl. 2014).

Andelen lyckade häckningar är däremot betydligt lägre hos oss, $69 \%$, än de $76 \%$ som redovisas från Västergötland (Ericsson m. fl. 2014). Det fanns inget statistiskt signifikant samband mellan antal ungar per kull och hur många häckningsförsök som gjordes (linjär regression på årsmedelvärdena, $b=0,046 \pm 0,070$ (se), $p=0.52$ ).

Boplundring har bidragit till en hög andel misslyckade häckningar. Mård (Martes martes) har vid några tillfällen påträffats $\mathrm{i}$ holkarna och $\mathrm{i}$ ett par fall har de haft sina ungar där. I många fall där vi vid ett tidigt besök konstaterat små uggleungar och holken sedan varit tom när vi kommit för att ringmärka, har vi antagit att mård tagit ungarna. I ett par fall har ungar legat ihjälbitna kvar i holken. Andelen holkar som plundrats på ägg eller ungar uppgår till $23 \%$. Även knipan (Bucephala clangula) konkurrerar med ugglor om vissa holkar och ofta vinner kniporna. Det händer varje år att det ligger ägg av båda arterna $\mathrm{i}$ någon holk och ugglorna har då fått ge upp. Skogsarbete med störning intill boplatsen och holkar med övergivna ägg (i några fall med trafikdödade häckfåglar eller att föräldrarna förolyckats på annat sätt) svarar för totalt $8 \%$ misslyckade häckningar av kontrollerade fall.

Kullstorleken (antal märkstora ungar) varierade mellan 1 och 7 (Tabell 2), men hela 92,9 \% av kullarna innehöll fyra ungar eller färre. Kullar med sex ungar har vi bara haft under toppåren, 1996, 1999 (3 kullar), 2003 (2), 2007 (2), och 2010 (4). År 2003 fann vi också en kull med sju ungar. Dessa fick märkas i två omgångar, alla sju blev flygga. För kattuggla var nio av kullarna med 6-7 ungar i ren bokskog, övriga fyra i blandad lövskog med mycket ek.

Det genomsnittliga antalet ringmärkta ungar per kull är i vår undersökning något lägre än

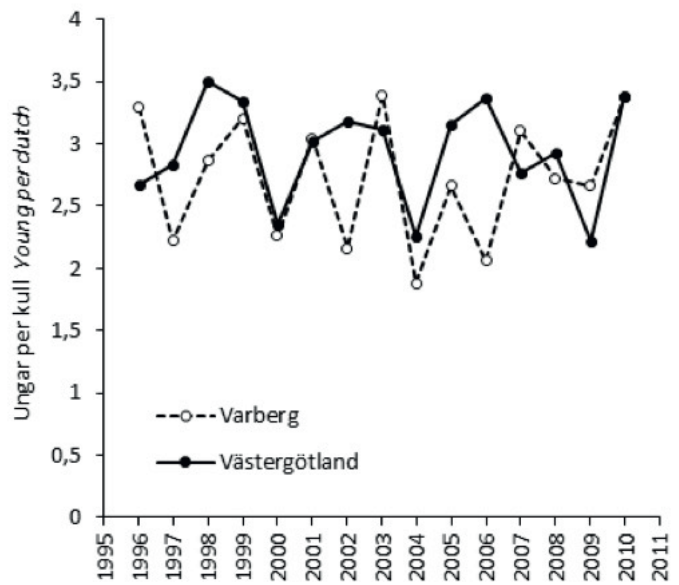

Figur 7. Medelantalet ungar per lyckad häckning hos kattuggla 1996-2010, i Varberg respektive i en motsvarande studie i Västergötland (Ericsson m. fl. 2014).

The average number of young per successful breeding in Tawny Owl 1996-2010, in Varberg and in a similar study in the nearby province of Västergötland (Ericsson et al. 2014)

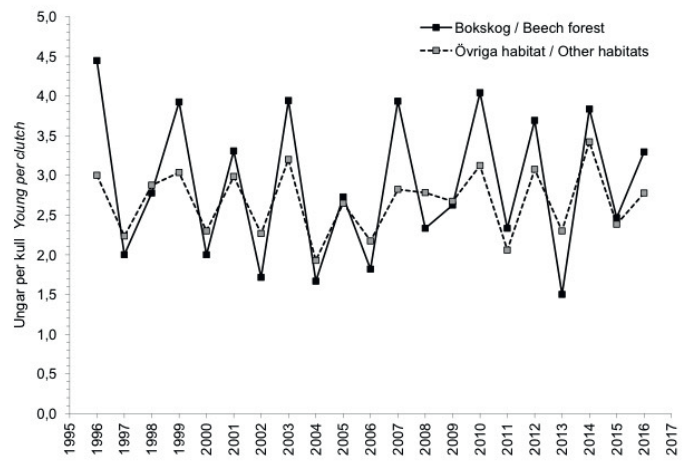

Figur 8. Det genomsnittliga antalet kattuggleungar per kull och år (1996-2016) i revir dominerade av bokskog respektive i övriga naturtyper. Notera att antalet ungar per år varierar mer mellan åren i bokskogen än i övriga områden.

The average number of Tawny Owl young per clutch per year (1996-2016) in territories dominated by beech forest, and in other habitats, respectively. The variation between years is larger in the beech forest than in the other habitats.

den i Västergötland, 2,86 mot 3,00 (Ericsson m.fl. 2014). Antal ungar per häckförsök kan i vårt material beräknas till 1,97 (med samma metod som för ormvråk, se ovan). Projektet i Västergötland redovisade 2,34 ungar per påbörjad häckning (Ericsson m. fl. 2014).

Variationen i antal häckande par mellan åren var stor i vårt område (Tabell 6), främst beroende på den 
stora skillnaden i antal par som genomför häckning i våra bokskogar under bra respektive dåliga år. Skillnaden mellan åren var till synes större än den var i Västergötland under motsvarande period (1996-2010, Ericsson m.fl. 2014). Med några få års undantag varierade häckningsframgången i de två projekten på ett liknande sätt (Figur 7). Toppåret i båda undersökningarna var 2010 då både antal lyckade häckningar och antal ringmärkta ungar var speciellt höga. Jämförelsen mellan Varberg och Västergötland antyder att viktiga faktorer för kattugglans häckningsframgång samvarierar över större områden, den mest troliga förklaringen är födotillgång.

En del av kattugglorna i Varbergs kommun häckade i revir med mycket bokskog, i genomsnitt $21 \%(6-37 \%)$ per år. Medelantalet ungar per kull varierade mer mellan åren inom bokskogsrevir (1,50-4,44 ungar per kull/år) än inom reviren i övriga habitat (1,93-3,42 ungar per kull/år, Figur 8). Den stora variationen mellan åren vad gäller antalet ungar i bokskogsbon beror i huvudsak på om det varit ett ollonår hösten före eller inte (Philipsson 2001). Skillnaden mellan åren i antal häckningar och ungar per kull i bokskog är dock större för kattuggla än för ormvråk. Variationen i antal ungar per kull överensstämmer mycket väl mellan arterna även i övriga habitat (Figur 4 och 8).

Sedan 1998 har vi registrerat äggkullstorlek, om det varit ägg i holken vid en första kontroll. Detta har sedan jämförts med antal ringmärkta ungar. I övriga holkar under respektive år har det redan varit ungar vid vårt första besök (Tabell 7). Det ringmärktes fler ungar per kull i de holkar som redan haft ungar när vi besökt dem än i de holkar där det var ägg vid första besöket. Detta speglar rimligen att ju tidigare på året en kull har påbörjats, liksom hos ormvråken, desto större kullar. Kläckningsframgången i vår studie var högre än i studien i Västergötland, 73,5 mot $67,2 \%$ (Ericsson m. fl. 2014).

\section{Kattugglan i Varbergs kommun}

Kattugglor häckar i alla typer av terräng där det finns tillgång till öppna marker eller glesa skogar att jaga $\mathrm{i}$. Vi har inte funnit några ugglor $\mathrm{i}$ stora granplanteringar och inte heller försökt sätta upp holkar i sådan miljö. Brist på lämpliga boträd är mycket stor i dagens hårt drivna skogsbruk. Vi har funnit ugglor häckande i bon av ormvråk, spillkråka, korp och skata samt i klippskrevor, ladugårdar och uthus. De naturliga trädhål som finns är mycket få. Holkuppsättning ger fåglarna en bra skyddad boplats att föda upp sina ungar i.
Beståndet fluktuerar betydligt mellan åren beroende på att tillgång på gnagare växlar. En höst med god fruktsättning i skogens träd, främst bok, samt en gynnsam vinter med snötäckt mark ger gnagare möjlighet att få många ungar tidigt. Under sådana förhållanden reagerar ugglorna med tidig och riklig häckning. Motsatt avstår många kattugglor från häckning ett år då gnagartillgången är dålig. De fåglar som ändå genomför häckning får färre ungar än normalt. Kattugglans antal ungar per kull varierar mellan goda och dåliga år nästan exakt som ormvråkens i vårt område (Figur 9).

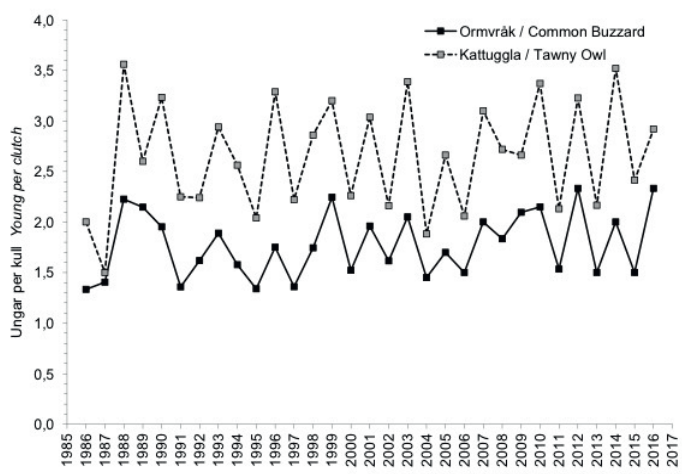

Figur 9. Det genomsnittliga antalet ormvråksungar och kattuggleungar per kull och år i Varbergs kommun 1986-2016. The average number of Common Buzzard and Tawny Owl young per clutch per year in Varberg 1986-2016

\section{Ormvråk och kattuggla}

Ormvråk är jämte sparvhök den vanligaste rovfågeln i vårt område, men det är ormvråken man oftast ser, både under häckningstid och under övrig tid på året. Det är de äldre vråkarna som stannar kvar hela vintern $\mathrm{i}$ vårt milda västkustklimat, ungfåglarna flyttar i allmänhet söderut. Kattuggla är den i särklass vanligaste ugglan i Varbergs kommun och fåglarna är till största delen stannfåglar.

Den tydliga samvariationen mellan arterna vad gäller antalet ungar per år indikerar starkt att de har ett högst liknande födoval (Figur 9). Här spelar bokens frösättning uppenbarligen en stor roll genom att ge förutsättningar för regelbundet förekommande gnagartoppar (Philipsson 2001). Vartannat eller vart tredje år har varit bra för båda arterna medan båda arterna fått färre ungar under mellanåren (korrelationsanalys på årsmedelvärdena, $\mathrm{r}^{2}=0,67, \mathrm{p}<0,001, \mathrm{~N}=31$ ).

Fokus i vårt arbete med fåglarna har under de första åren varit på ormvråk medan ugglorna dominerat därefter. Antalet märkta ormvråkskullar 
varierar mest beroende på vår arbetsinsats, förutom under 1990-talet då vi fann betydligt fler revir ute på och intill kustslätten. Antal märkta kattugglekullar visar variationer på ungefär samma antal revir under åren 1998-2016, den period vi hade mest fokus på arten. Det skiljer drygt en unge per kull mellan ormvråk och kattuggla och förhållandet är ungefär lika varje år. Den stora skillnaden är att ugglorna är betydligt mer känsliga för brist på föda och sådana år avstår de från att försöka häcka. En större andel av ormvråkarna bygger på sitt bo och lägger ägg, även om de făr tydligt färre ungar under år med dålig födotillgång.

\section{Tack}

Projektet har fått ekonomiskt stöd under olika år av Elis Wides och Gustaf Danielssons fonder, Margareta och Sten-Oves Lindbergs stiftelse, Sveriges Ornitologiska Förening samt av Alvins Fond, Naturvårdsverket. Bidrag och material till holkar har erhållits från Länsstyrelsen i Halland, Gyproc $\mathrm{AB}$, Ringhals $\mathrm{AB}$, Värö Såg, Varbergs kommun och Varbergs Ornitologiska Förening. Sydved $\mathrm{AB}$ har sponsrat vår specialstege. Tack till Anders Andersson, Björn Bengtsson, Magnus Forsberg, Andrea Gålnander, Stefan Hage, Per-Arne Johansson samt alla övriga som under olika tider deltagit eller stöttat projektet. Utan dessa hade vi inte lyckats som vi gjort. Ett stort tack också till alla markägare som visat intresse och låtit oss arbete på deras marker. Tack också för uppgifter om ormvråk i andra delar av landet som lämnats av; Jan Bergkvist, Thomas Dahlgren, Bill Douhan, Tommy Järås och Bengt Wiklund. Ett särskilt tack till Åke Lindström för hjälp med synpunkter på manuskriptet.

\section{Referenser}

Dare, P. J. 2015. The life of Buzzards. Whittles.

Douhan, B. 2017. Ormvråken inpå livet. Fåglar i Uppland 44: 24-35.

Ericsson, P., Nilsson, L.-O., Haglund, K. \& Ericsson, D. 2014. Breeding biology of a Tawny Owl Strix aluco population in southwestern Sweden - a 15 year survey. Ornis Svecica 24: 41-50.

Erlinge S., Göransson G., Hansson L., Högstedt G., Liberg O., Nilsson I. N., Nilsson T., von Schantz T. \& Sylvén M. 1983. Predation as a regulating factor on small rodent populations in southern Sweden. Oikos 40 36-52.

Goszczyński, J. 1997. Density and productivity of Common Buzzard Buteo buteo and Goshawk Accipiter gentilis populations in Rogów, Central Poland. Acta ornithlogica 32: 149-154.

Goszczyński, J. 2001. The breeding performance of the Common Buzzard Buteo buteo and Goshawk Accipiter gentilis in Central Poland. Acta ornithlogica 36: 105-110.
Green, M., Haas, F. \& Lindström, Å. 2018. Övervakning av fåglarnas populationsutveckling. Årsrapport för 2017. Rapport, Biologiska institutionen, Lunds Universitet. 95 pp.

Jørgensen, H. E. 1989. Danmarks rovfugle-en statusoversigt. Frederikshus. 199-242.

Länsstyrelsen i Halland. 1994. Miljövårdsprogram.

Länsstyrelsen i Halland. 2004. Miljövårdsprogram inför ett nytt århundrade. Länsstyrelsen i Halland.

Länsstyrelsen i Halland. 2007. Strategi för formellt skydd av skog i Hallands län. Meddelande 2007:5 från Länsstyrelsen i Hallands län.

Malmström, C. 1939. Hallands skogar under de senaste 300 åren. Meddelanden från Statens Skogsförsöksanstalt 31: 171-300.

Mebs, T. 1964. Zur Biologie und Populationsdynamik des Mäusebussards (Buteo buteo) (Unter besonderer Berücksichtigung der Abhängigkeit vom Massenwechsel der Feldmaus Microtus arvalis). J. Orn. 105:247-306.

Persson, M. 2003. Habitat quality, breeding success and density in Tawny Owl (Strix Aluco). Ornis Svecica 13:137-143.

Philipsson, C. 2001. Kattugglor, skogsmöss, bokar, väder och växthuseffekt. Blekinge Natur 2001: 13-32.

Reif, V., Tornberg, R., Jungell, S. \& Korpimäki, E. 2001. Diet variation of common buzzards in Finland supports the alternative prey hypothesis. Ecography 24: 267-274.

Reif, V., Jungeil, S., Korpimäki, E., Tornberg, R. \& Mykrä, S. 2004. Numerical response of common buzzards and predation rate of main and alternative prey under fluctuating food conditions. Ann. ZooI. Fennici 41: 599-607.

Rockenbauch, D. 1975. Zwölfjährige Untersuchungen zur Ökologie des Mäusebussards (Buteo buteo) auf der Schwäbischen Alb. Journal für Ornithologie 116: 39-54.

Rodríguez, B., Siverio, F., Rodríguez, A., Siverio, M., Hernández, J. J. \& Figuerola, J. 2010. Density, habitat selection and breeding biology of Common Buzzards Buteo buteo in an insular environment. Bird Study 57, 75-83.

Spidsø T. K. \& Selås V. 1988. Prey selection and breeding success in the Common Buzzard in Buteo buteo relation to small rodent cycles in southern Norway. Fauna norv. Ser. C, Cinclus 11: 61-66

Swan, G. 2011. Spatial variation in the breeding success of the Common Buzzard Buteo buteo in relation to habitat type and diet. M. Sc. Thesis, Imperial College, London.

Svensson, S., Svensson, M. \& Tjernberg, M. 1999. Svensk fågelatlas. Vår fågelvärld, supplement 31, Stockholm.

Sylvén, M. 1982. Reproduction and survival in Common Buzzards (Buteo buteo) illustrated by the seasonal allocation of energy expenses. $\mathrm{PhD}$ dissertation, Lund University, Sweden.

Tubbs, C. R. 1974. The Buzzard. David \& Charles, Newton Abbot \& London.

Wallin, K. 1988. Life history evolution and ecology in the tawny owl (Strix aluco). PhD. Thesis. University of Gothenburg.

Wirdheim, A. 2014. Hallands fågelatlas. Hallands ornitologiska föreningar, Halmstad

Wirdheim, A. \& Carlén, T. 1986. Fågelstråk. Hallands fågelliv $i$ ord och bild. Spektra, Halmstad.

Wirdheim, A. 2014. Hallands fågelatlas. Hallands ornitologiska föreningar, Halmstad.

Wretenberg, J., Lindström, Å., Svensson, S. \& Pärt, T. 2007. Linking agricultural policies to population trends of Swedish farmland birds in different agricultural regions. J. Appl. Ecol. 44:933-941. 


\section{Summary}

The aim of this project was to follow and document the situation for raptors and owls in Varberg municipality in southwest Sweden $\left(57^{\circ} 10^{\prime} \mathrm{N}, 12^{\circ} 10^{\prime} \mathrm{E}\right)$, in the light of the ongoing and rapid changes in the surrounding landscape. What started as a five year project resulted in detailed breeding performance data being collected over 33 years (1984-2016). The ambition in the field was to find as many raptor and owls nests as possible, to follow up on their breeding success and to ring the chicks. We here present data on the habitat choice, nest placement and breeding success of Common Buzzard Buteo buteo and Tawny Owl Strix aluco. The work was carried out in our spare time up to 1997, and after that at a full time scale, especially in spring and summer.

Great changes have taken place within both agriculture and forestry in our study area. Many small farms have been aggregated into larger units and been turned into pure husbandry or only producing grain. Especially in more forested parts of the area, many fields have been abandoned and planted with spruce. This has affected both the breeding and foraging sites of raptors and owls. One key change at the landscape scale took place in 1987-1995, when farmers were paid to take their land out of production, which created many set-aside fields highly suitable for raptors and owls feeding on small rodents.

Varberg municipality $\left(900 \mathrm{~km}^{2}\right)$ has been surveyed with different intensity in different areas (Figure 1 and 2). Area 1 can be described as coastal plains, whereas areas $2-5$ contain forested land at higher elevations (mainly in the east), with a farmland forest mosaic landscape in between.

\section{Common Buzzard}

Previously known nests, and new nests found during winter, were followed up in April and May, to check for signs of breeding. In the second half of May and in June, we checked for young in the nests. Breeding attempts with nestlings present at these visits were deemed successful. Forest type and height of the nest tree were also recorded. In the most intense period, 1990-2011, we checked at least 100 territories yearly. From body mass and wing measurements of ringed chicks, hatching dates for the oldest young in each clutch has been estimated. For each year we established an average first hatching date and an average brood size (number of chicks at ringing).

Data are presented for either 1984-2016 or the most intense study period (1986-2011, Table 1, Figure 3). The number of known territories increased up to 1995 and declined thereafter, partly because of our increased efforts and partly due to the positive effect of set-aside fields during the same period. After 1995, fewer breeding attempts were found, reflecting both a true decline and a smaller effort.

The number of young per clutch varied between 1 and 4 (Table 2). There was no change over time in the number of young per successful breeding (linear regression on yearly averages, $b=0.007 \pm$ 0.008 (se), $\mathrm{p}=0.38$ ). Mean brood size varied between 1.33 and 2.24, with a total average of 1.74 young per clutch. Only in the very best years were there clutches with four young raised. Of these, nine were in beech forest, two in mixed forest and one each in oak, alder and pine forest, respectively. Comparable data from both published and unpublished studies are presented in Table 3. Overall there was only small variation in brood size between the different areas of the municipality (Figure 1 and 2). The number of raised young per breeding attempt cannot be calculated with high accuracy, but is likely to be about 1.28 over the whole study period.

There was clearly a larger between-year variation in brood size in territories in beech forest than in territories situated in other habitats (Figure 4). A large beech mast crop results in a good breeding success the following year, creating a larger variation than in other habitats.

Most Common Buzzard nests were found in pine trees. In total 2040 breeding attempts in 846 nest trees were checked, which is 2.41 per tree (Table 4). In total $74.1 \%$ out of 1512 breeding attempts were successful. The nests were normally placed in the upper third of the nest tree, at a height of 10-15 m (Table 5), most often near the trunk. The breeding success varied slightly with forest type, being highest in beech and lowest in alder-birch (Figure 5).

The hatching date of the first young could vary with up to a month in a given year. Brood size generally decreased with laying date (linear regression on yearly means, $b=-0.061 \pm 0.012(\mathrm{se}), \mathrm{p}<0.001$, Figure 6 ), with yearly means varying between 10 and 24 May.

Overall, Common Buzzards in our study area have in the last two decades been affected by the loss of the beneficial set-aside areas (many returned to crop production again), the loss of semi-natural grasslands, ditches and other small biotopes rich in rodents, and not least the plantation of spruce, 
which has been particularly intense in our study area. Spruce forests are generally poor for Common Buzzards.

\section{Tawny owl}

We started early on to put up nest boxes for Tawny Owls in what we thought were suitable areas. It soon became clear that there was a general lack of nest sites (such as old trees and old buildings). The number of nest boxes increased gradually up to 1998 and since then we checked about 300 nest boxes annually, often several times, from late March to May. Many adult birds were ringed, and most nestlings.

In 1986-2016 we noted 2009 breeding attempts, of which $69 \%$ were deemed successful (Table 6). Breeding success varied greatly between years, both as far as the number of breeding attempts and number of fledged young are concerned.

Nest predation, often by Pine Marten Martes martes, was a major cause of breeding failure. The proportion of nest boxes being robbed of eggs and young was 23\%. Common Goldeneyes Bucephala clangula compete with the Tawny Owls for nest boxes, and often the ducks outcompete the owls. Every year we found nest boxes with eggs from both species, and then the owls gave up. Disturbance due to forestry activities and loss of adults due to traffic or other causes together account for $8 \%$ failures out of all breeding attempts.

Brood size (the number of young large enough to ring) varied between 1 and 7 (Table 2), but 92.9 $\%$ of the clutches contained four or fewer young. All young of the single clutch with seven young fledged. Most of the largest clutches were found in pure beech forest. The average brood size was 2.86 and the number of young per breeding attempt was approximately 1.97 .
The variation between years in the number of breeding attempts was large (Table 6), mainly due to the larger variation among pairs breeding in beech forest. The variation was similar to a study in nearby province (Figure 7). Clearly the main factors for Tawny Owl breeding co-vary over large areas, most likely due to beech-mast related variation in food supply. Around $21 \%$ of the tawny Owls bred in more or less pure beech forest (6-37\% per year). Average brood size varied more in beech forest (1.50-4.44 young per clutch and year) than in other habitats (1.93-3.42 young per clutch and year, Figure 8). The underlying reason is the same as for Common Buzzard. Large beech mast crops lead to high rodent abundance and in turn good breeding conditions. The between-year variation is larger in the Tawny Owl than in the Common Buzzard, but the yearly pattern is very similar between the species (Figure 9).

Since 1998 we also recorded clutch size when there were eggs when a nest box was first visited. Clutch size was later compared with the brood size at ringing (Table 7). Hatching success was on average $73.5 \%$. There were on average more young in broods where there were nestlings already at the first visit, probably mirroring the pattern in Common Buzzards that clutch/brood size decreased with laying date.

Tawny Owls in our study area breed in all habitats with open fields or sparse forests for them to hunt in. We never found Tawny Owls in spruce forests (and we had no nest boxes there). Most nests were found in nest boxes, but we also found Tawny Owls breeding in old nests of Common Buzzard, Black Woodpecker Dryocopus martius, Raven Corvus corax and Magpie Pica pica, as well as in crevices, barns and sheds. Natural tree holes are simply very rare. 